\title{
Seismic stratigraphy and depositional history of the Büyükçekmece Bay since Latest Pleistocene, Marmara Sea, Turkey
}

\author{
Denizhan Vardar ${ }^{1, *}$, Hakan Alp ${ }^{2}$ and Bedri Alpar ${ }^{1}$ \\ ${ }^{1}$ Institute of Marine Sciences and Management, Istanbul University, 34134 Vefa, Istanbul, Turkey. \\ ${ }^{2}$ Department of Geophysical Engineering, Istanbul University, Avcılar, Istanbul, Turkey. \\ *Corresponding author. e-mail: denizhan@istanbul.edu.tr
}

MS received 28 February 2017; revised 15 June 2017; accepted 16 June 2017; published online 14 February 2018

High-resolution seismic data shed light on latest Pleistocene and Holocene sedimentation beneath the Büyükçekmece Bay, northern shelf area of the Marmara Sea, Turkey. Discontinuous fluvio-marine and marine deposits overlying the erosional truncation surface of Oligocene-Lower Miocene deposits are as thick as $30 \mathrm{~m}$ and preserved preferentially within the incised valleys that were controlled by some old faults. A series of prograding shoreline, laterally passing to the latest Pleistocene-Holocene valley-fill deposits, are thought to have accumulated mainly during times of shoreline transgression and sealevel rise. The overall morphology and stratigraphic setting observed in the Büyükçekmece Bay and at the southern outlet of the Bosphorus Strait have nearly same characteristics, implying that similar hydrodynamic conditions, erosional and depositional processes were mainly under the control of strong northerly flows during the Late Quaternary. These flows were less powerful in the Büyükçekmece region with decreased sediment input and smaller accommodation space.

Keywords. Büyükçekmece bay; seismic stratigraphy; sea level changes; prograding shoreline; incised valley; Bosphorus strait.

\section{Introduction}

The Marmara Sea is an intra-continental marine basin connected to the adjacent seas via the İstanbul and Çanakkale (Bosphorus and Dardanelles) straits. Their connections have been cut-off when the sea levels dropped below the respective sill depths (Smith et al. 1995; Aksu et al. 1999, 2002a, b, c, 2016; Çă̆atay et al. 2000, 2003, 2009; Eriş et al. 2007, 2008; Hiscott et al. 2002, 2008; McHugh et al. 2008; Vidal et al. 2010). Reconnection of the Marmara Sea with the global ocean was established with transition to interglacial period, as evidenced by sapropel deposits indicating suboxic/dysoxic conditions (Çăgatay et al. 1999, 2000, 2009). According to the continuous sedimentary records given by Çağatay et al. (2015), the last lacustrine-marine transition in the Marmara Sea occurred at $12.55 \pm 0.35$ cal ka BP. During the Last Glacial Maximum (LGM), the margins of the Marmara Sea were sub-aerially exposed (Smith et al. 1995; Aksu et al. 1999, 2002a, b, c; Çă̆atay et al. 2000, 2009; Eriş et al. 2007; McHugh et al. 2008).

The northern shelf areas of the Marmara Sea is relatively narrow, varying between 2 and $13 \mathrm{~km}$. 
Recent researches on the late Quaternary stratigraphy of this margin have been focused on the general characteristics of the younger and relatively thinner sediments overlying a shelf-crossing acoustic basement (Aksu et al. 1999; Olgun 2001; Çağatay et al. 2009; Karakılçık et al. 2014; Tur et al. 2014; Nasif 2016). In addition, seismic sequences at the southern outlet of the Bosphorus Strait have been discussed deliberately to explain paleo-outflow regime of this water passage (e.g., Aksu et al. 1999; Algan et al. 2001; Hiscott et al. 2002; Gökaşan et al. 2005; Eriş et al. 2007; Köprülü et al. 2016). Due to variable hydrodynamic conditions and high sediment input, the stratigraphic settings of the southern outlet of the Bosphorus Strait is thicker and more complex compared to the other parts of the Marmara Sea (Alavi et al. 1989).

Today's Küçükçekmece and Büyükçekmece lagoons (figure 1) were two semi-enclosed bodies of water connected to the Marmara Sea (lake) and fed by rivers at the north. These former coastal estuaries were separated from the Marmara Sea by some partly natural sand bars and manmade road barriers about a century ago. Gökaşan et al. (2002) proposed that these shallow water bodies and their shorelines have been shaped by some active NWtrending fault splays connected to the northern strand of the North Anatolian fault system in the eastern Marmara Sea. The Büyükçekmece Bay is located at the southern part of the Büyükçekmece lagoon. There is almost no comprehensive geophysical study in literature about the evolution of the bay. The sedimentation observed in the bay, however, is much thicker if compared to thin Holocene blanket outside the bay. Therefore, the sedimentary successions in the bay interpreted with sufficiently better seismic data may provide a detailed explanation of the late Quaternary evolution. The main scope of the present study is to explain the stratigraphic setting in the Büyükçekmece Bay and to reconstruct its evolution. High-resolution shallow seismic profiles and available sedimentary core data provided necessary information for the construction of sedimentary environments in this bay.

\section{Materials and methods}

Shelf sediments distributed in the Büyükçekmece Bay area and their deposition were studied extensively using (i) two sets of high-resolution seismic data, (ii) sedimentary core data and (iii) by considering the sequence stratigraphic concepts (Vail
1987; Posamentier and Vail 1988; Posamentier et al. 1992).

Single channel high-resolution Sparker $(72 \mathrm{~km}-$ line, $250 \mathrm{~ms}$ two-way-time) and Chirp (128 km-line, $100 \mathrm{~ms}$ two-way-time) seismic surveys have been acquired in the Büyükçekmece Bay (figure 1) in 2000 and 2015, respectively. The Sparker system is composed of $1.25-\mathrm{kJ}$ multi-electrode spark array and an 11-element, 10-m-long surface-towed hydrophone streamer. Sparker data provided information on sedimentary deposits up to $150 \mathrm{~m}$ below the seabed. In order to obtain much detailed sub-bottom survey capability especially for shallow waters, Bathy $2010 \mathrm{P}^{\mathrm{TM}}$ Chirp sub-bottom profiler and bathymetric echo sounder $(2-8 \mathrm{kHz})$ was used. The transmit pulse repetition rate was $1 \mathrm{~Hz}$ depending on the depth range and also on the selected pulse length which is short enough in order to resolve thin layers covering the subbottom strata. The vessel speed was held as slow as 2.0-2.5 knot throughout the Chirp survey. The approximate depths were calculated using a typical velocity $1500 \mathrm{~ms}^{-1}$ both for water column and near-surface muddy sediments. Some primary processing such as gain correction, band-pass filter (10/15-1750/1900 Hz) and predictive deconvolution were applied to datasets using free software Kogeo Seismic Toolkit. Kingdom Suite ${ }^{\circledR}$ (version 8.5; donated by Seismic MicroTechnology) was used for seismic data interpretation and mapping. The relief maps (unit thickness and surface depth maps) were generated by Global Mapper program and the land elevation data were provided from ASTER 2 data.

\section{Results}

A total of $200 \mathrm{~km}$-line high-resolution seismic data have been analysed and interpreted to represent the last glacial to recent sediment succession (MIS2 to MIS-1) and morphological properties of the Büyükçekmece Bay and offshore area.

\subsection{Seafloor morphology}

The bathymetry map that generated from high resolution seismic data, revealed a NE-SW trending valley system (figure 2 ). This valley system is widening in the interior of the bay $(\sim 3000 \mathrm{~m})$ and it becomes narrower to the south with a control of coastal basement rocks (figure 2). It has an asymmetric cross-section with gentle bounding walls; approximately $1.5^{\circ}-2^{\circ}$ slope along its western side 

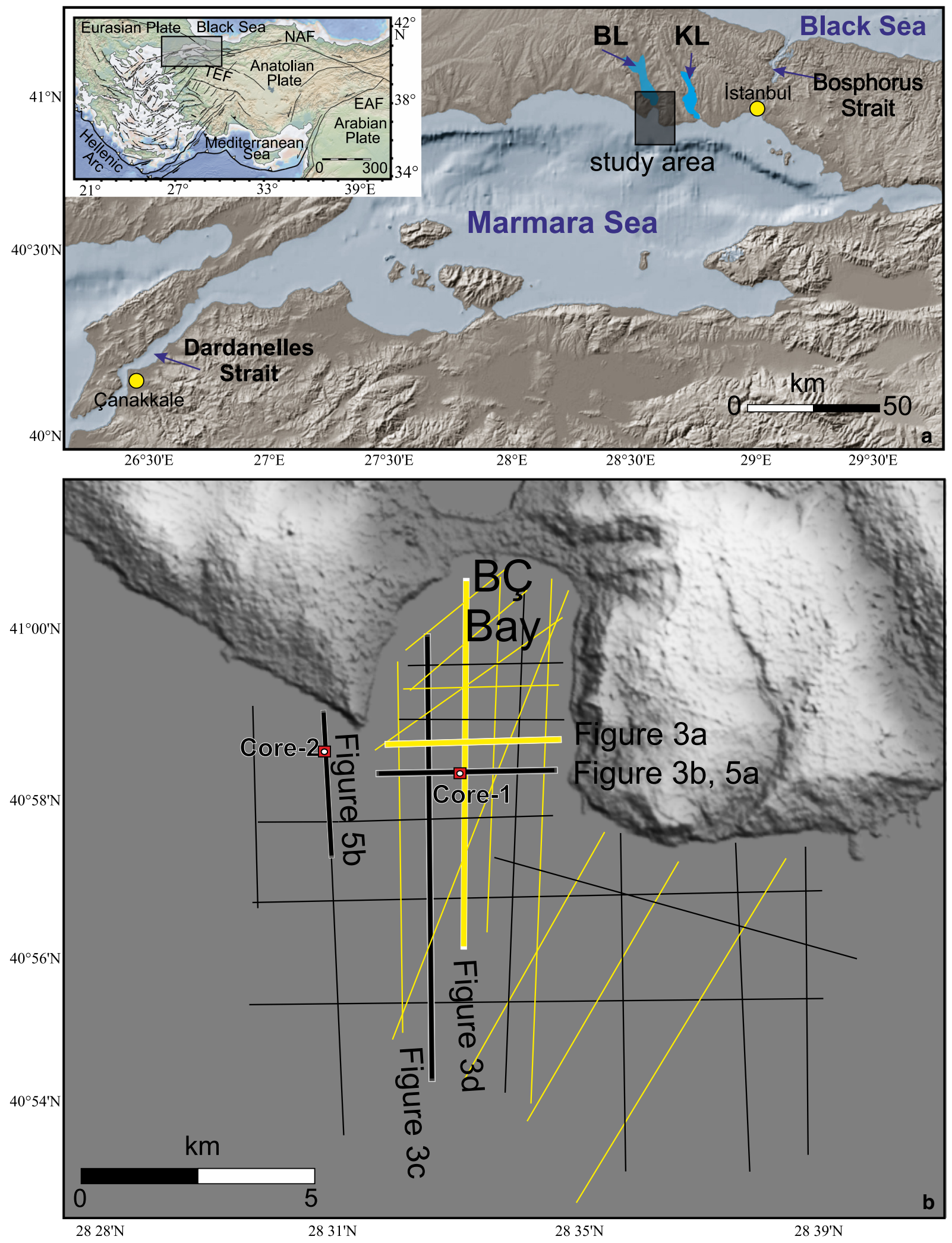

Figure 1. (a) Location of the Büyükçekmece Bay (BÇ) and Büyükçekmece Lagoon (BL) which are separated by a narrow barrier bar. KL: Küçükçekmece Lagoon. Inset shows a generalized tectonic setting of the region. Shaded box stands for the study area. (b) The cores and seismic reflection profiles acquired by Sparker (yellow lines) and CHIRP (black lines) systems. Heavy lines are seismic profiles illustrated in figures indicated. 


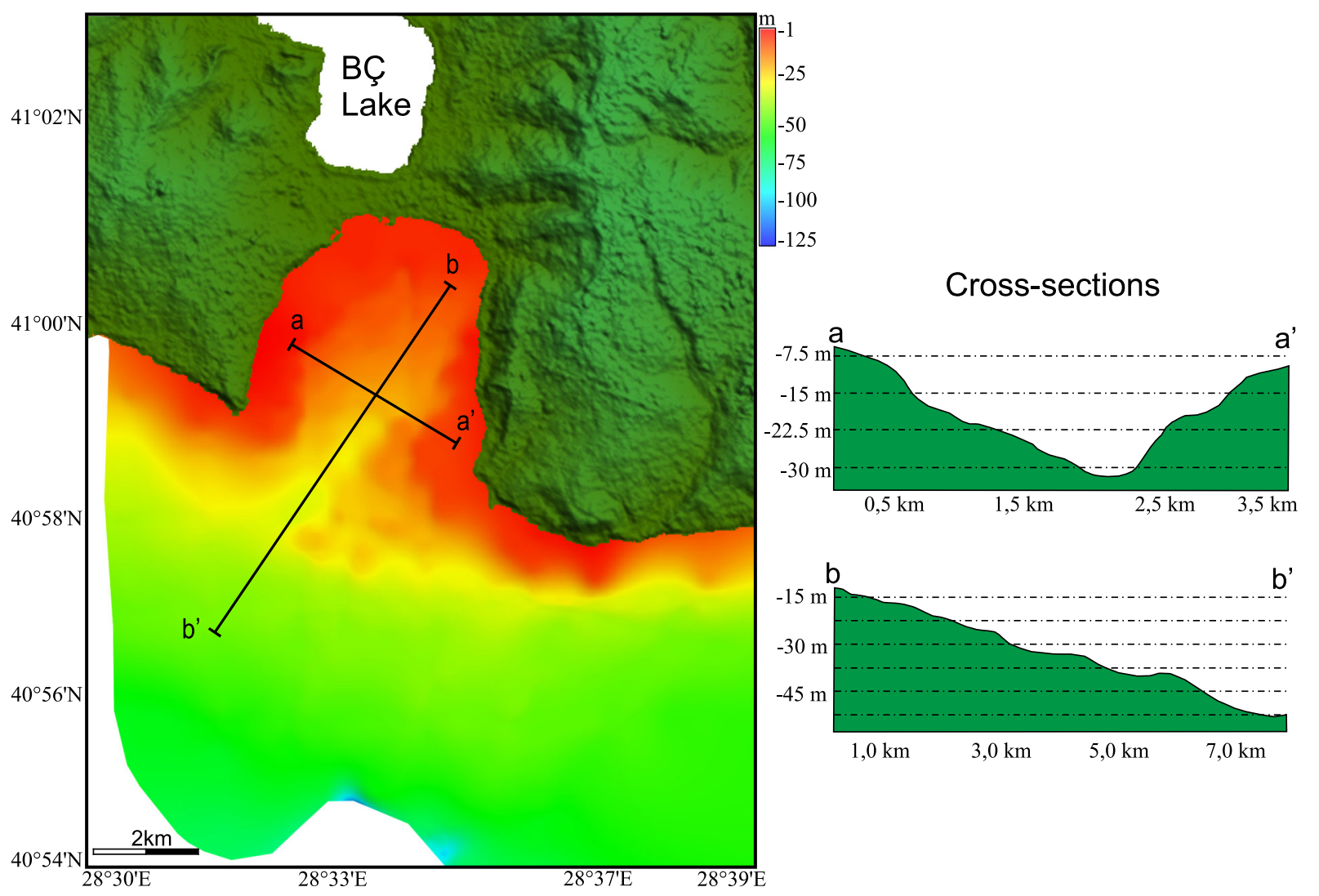

Figure 2. Detailed bathymetry of the Büyükçekmece Bay compiled using more than 200 line-km of seismic profiles collected during two cruises. Depths are calculated using $1500 \mathrm{~ms}^{-1}$ for water velocity. The seafloor morphology is mainly under the control of a SW-trending valley.

and $3^{\circ}-5^{\circ}$ slope along its eastern side (figure $2 \mathrm{a}$ ). The valley system deepens gently to the south with a slope $0.5^{\circ}-1^{\circ}$ and presents a series of terraces (figure $2 b$ ).

\subsection{Seismic stratigraphy}

The application of sequence-stratigraphic concepts, using high-resolution seismic records as a tool, gives good clues about the spatial and temporal record of the stratal development in response to sea-level changes, and therefore about the surrounding environmental processes occurred during their formation (Van Wagoner et al. 1988). A river delta, for example, is a gateway for terrigenous sediment flux and may occur where a river enters a sea, lake or estuary. Therefore, the extensive definition of individual or stacked delta sequences in basins, their morphology and stratigraphy, could provide better understanding of the significant environmental processes within the basin's geological setting, and even tectonics.

The seismic profiles acquired in the Büyükçekmece Bay (see figure 1 for location) revealed two main seismic units (U1 and U2), which are separated by a characteristic sequence boundary covering the whole study area (figure 3a, $\mathrm{b}, \mathrm{c}, \mathrm{d})$.

U1: It is the uppermost seismic unit and composed of several different reflection packages, which are represented by weak to moderate, continuous and sigmoidal reflections (figure $3 \mathrm{a}, \mathrm{b}, \mathrm{c}, \mathrm{d}$ ). The Unit U1 overlies directly on an erosional transgressive surface and reaches a maximum thickness of $30 \mathrm{~m}$ (figure 4) at the centre of the bay with respect to the morphology of the underlying valley system (figure 2). This unit represents all the sediment successions that synchronously deposited during the last glacial maximum to present time.

These sedimentary successions are composed of six relatively conformable units of genetically related succession of bed sets; U1a, U1b, D1, D2, D3 and D4 with some characteristic seismic internal reflections, bounded by marine flooding surfaces and their correlative surfaces (figure 3a, b, c, d).

U1a: This unit is characterized by weak to strong, parallel and continuous internal reflections, 


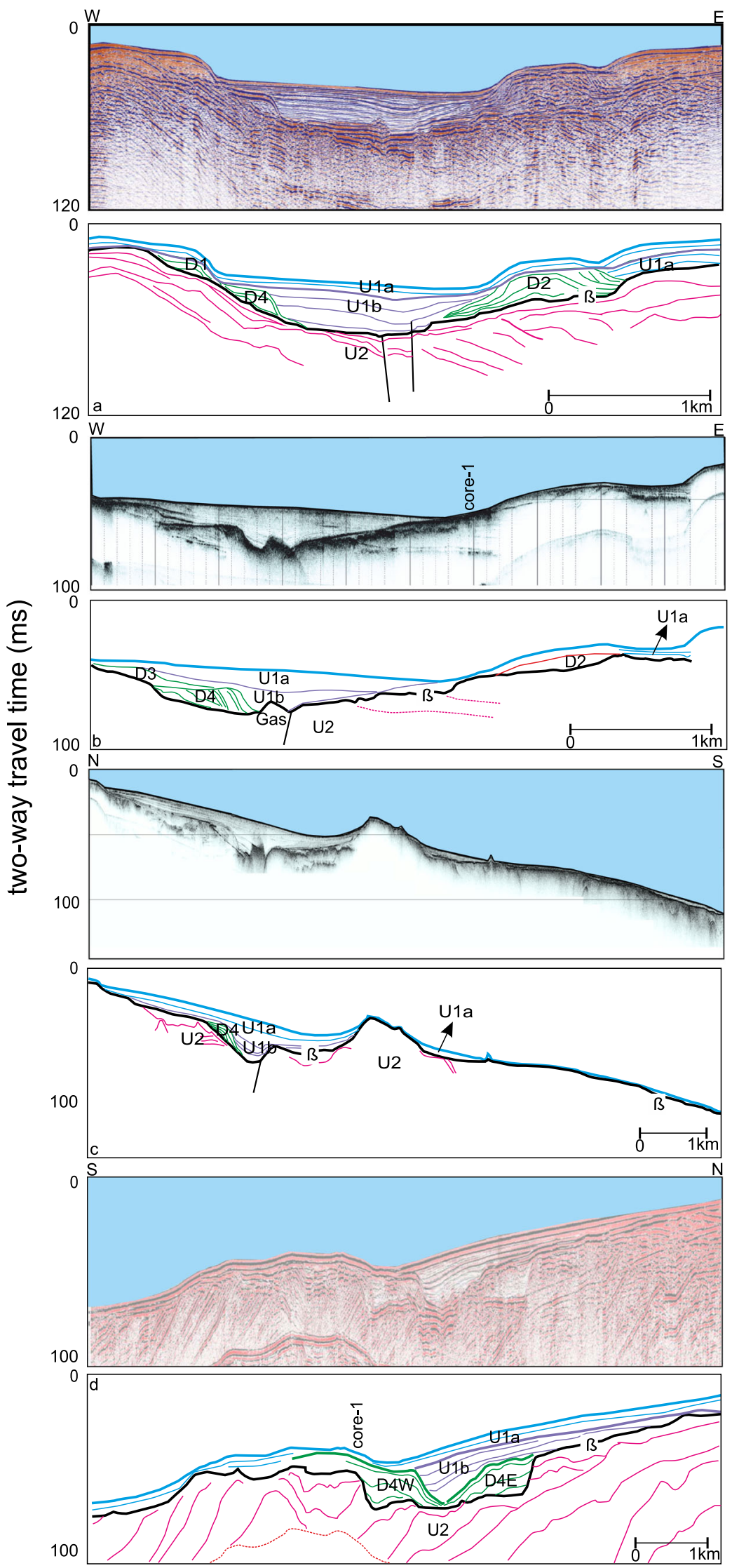

Figure 3. Sparker and CHIRP sections and their interpretations. See figure 1 for locations. The position of Core-1 is projected (max. $25 \mathrm{~m})$ on the seismic lines. 


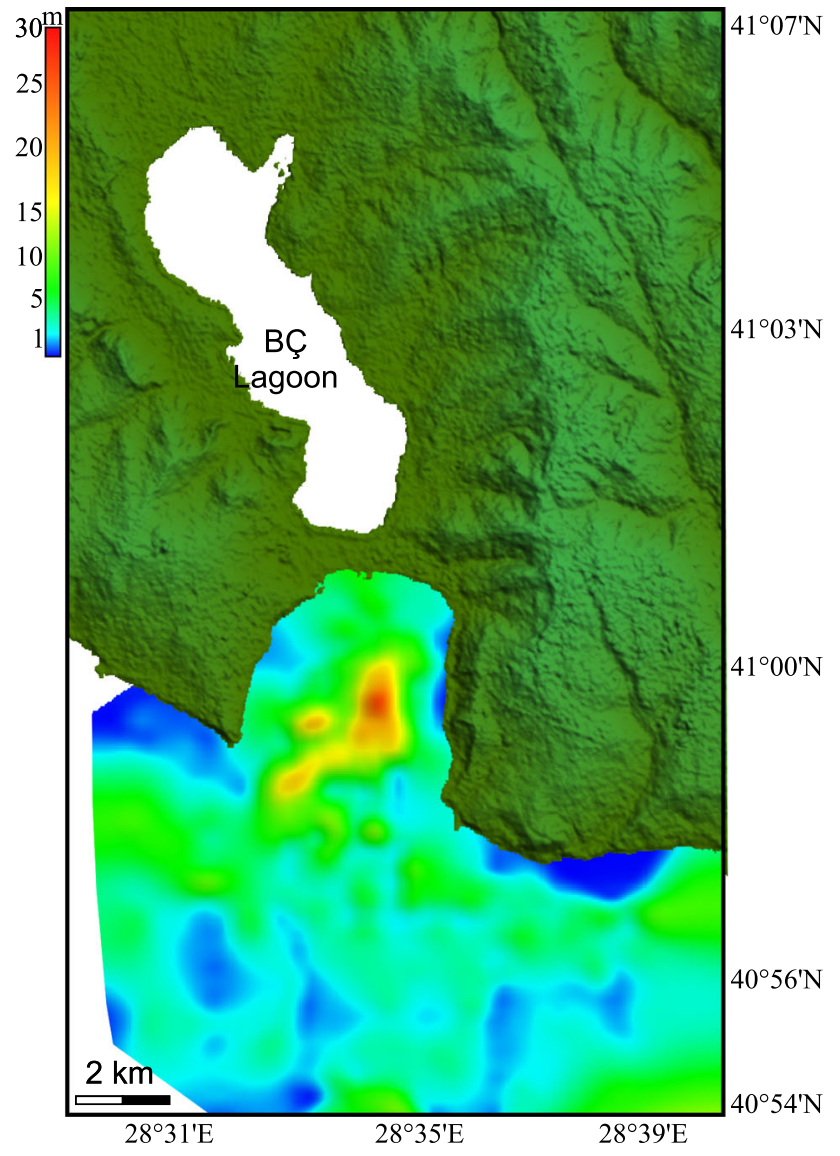

Figure 4. Thickness map of Unit 1, according to an assumed acoustic velocity of $1500 \mathrm{~ms}^{-1}$ (Aksu et al. 2016) for sediment.

with some onlaps on the underlying unit (U1b) and sigmoidal reflections. The unit can be seen within the Büyükçekmece Bay. It is composed from coarse-grained sand (loose to medium dense) and shell fragments at the top of the cores (figure 5).

U1b: Unit U1a is underlain by a relatively conformable Unit (U1b), which is characterized by semi-parallel inner reflections infilling local depressions and onlapping an unconformity surface $\beta$ and some sigmoidal reflections (figure $3 \mathrm{a}, \mathrm{b}, \mathrm{c}, \mathrm{d}$ ). The amplitudes are low within the dominant frequency range of the Chirp data, but moderate in the Sparker data. This unit cannot be seen above - $35 \mathrm{~ms}$ two-way-travel time below mean sea level $\left(-26 \mathrm{~m} ; \mathrm{Vw}=1500 \mathrm{~ms}^{-1}\right)$. The deepest part of the basin is masked partly by acoustic turbidities due to shallow gas accumulations. In the gravity core Core- $1 / 2$, this unit is composed from gravel (loose to medium dense) and abundant shell fragments (figure 5).

Four separate small subaqueous sigmoidal units have been observed at the western and eastern sides of the U1b; namely D1, D2, D3 and D4 (figure 6). These units have been characterized by prograding subaqueous clinoforms, a 'topsetforeset-bottomset' depositional profile, implying a high-energy (fluvial-riverine) environment. They downlap on to the underlying erosional surface, interpreted as a stable platform, and their topsetforeset rollovers are located close to the shoreline.

D1: The highest subaqueous prograding shoreline unit in elevation is D1 and it is located at the western side of the bay, the topset-foreset transitions between the depths of 26 and $30 \mathrm{~ms}$ two-way-travel time below mean sea level (figure 6). The topset-foreset transitions of D1 show an ascending trajectory.

D2: This is a prograding shoreline unit with topset-foreset transitions between the depths of 36 and $46 \mathrm{~ms}$ two-way-travel time below mean sea level and it is observed at the eastern side of the bay. The inner reflections along the $\mathrm{E}-\mathrm{W}$ trending profiles are similar to levee deposits (figure 6), whilst the topset-foreset transitions of D2 show ascending trajectory along the $\mathrm{N}-\mathrm{S}$ trending profiles (figure 6).

D3: This prograding shoreline unit is located at the western side of the bay, but it is deeper than D1. Its topset-foreset transitions are between 44 and $46 \mathrm{~ms}$ two-way-travel time below mean sea level (figure 6). The seismic character of the topset-foreset transitions express an erosive character, as well as sediment by-pass. The clinoforms at the distal part downlap on to the underlying Unit D4.

D4: This unit overlies the erosional truncation surface $\beta$ that is fault controlled at the western side of the bay (figure 6). The topset-foreset transitions of D4 is between the depths of 57 and 61 ms two-way-travel time below mean sea level and represent an ascending trajectory. The unit first filled an old valley and then eroded due to fluvial forces (figure 3d). Its high-amplitude topset reflections represent a bypass surface.

U2: This unit is the acoustic basement of the CHIRP data. In Sparker profiles, the Unit U2 is represented by locally tilted, folded and faulted reflectors throughout the study area (figures 3a, b, c, d). The most striking faults were observed below the NE-SW extending buried valley in the bay area (figure 3a). The upper surface of U2 is made up of sandy, highly altered and weathered deposits, depending on the bottom part of the gravity core Core-2 (figure 5). This unit corresponds to the Upper Gürpınar formation (Oligocene-Lower 

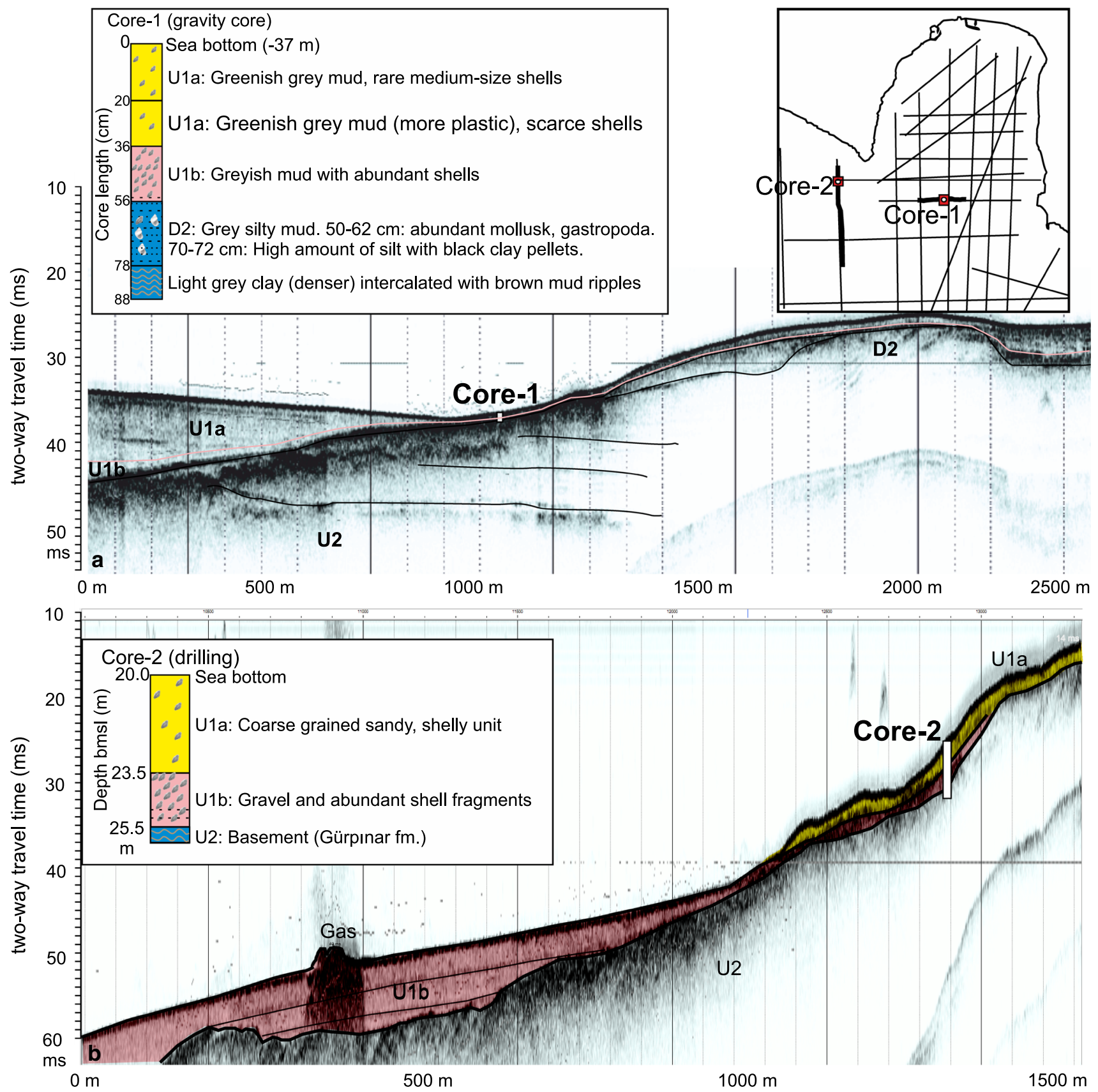

Figure 5. Relations of lithologic definition obtained from the cores (gravity and drilling) and their relation with seismic units. Inset shows the locations of the gravity cores and seismic profiles.

Miocene) observed on land, composed from gravelly clay, occasional sand and silt alternations (Yildirim et al. 2013).

In this scope, the boundary between the Units $\mathrm{U} 1$ and $\mathrm{U} 2$ represents an ancient subaerial exposure surface (ß). Outside the Büyükçekmece Bay, this erosional surface is just below the thin Holocene deposits, and normally concordant with the present bathymetry all across the northern Marmara shelf. This view is different in the Büyükçekmece Bay demonstrating fluvial scoured topographic features and prograding shoreline deposits (figure 7). These dynamic features must be evolved along a NEtrending valley and under the control of an old fault system located in the deepest part of this valley.

\section{Discussion and conclusion}

There is no any comprehensive seismic study ever performed on the seismic stratigraphic evolution of the Büyükçekmece Bay, except a number of seismic lines recorded in the previous works carried out on the northern shelf of the Marmara 

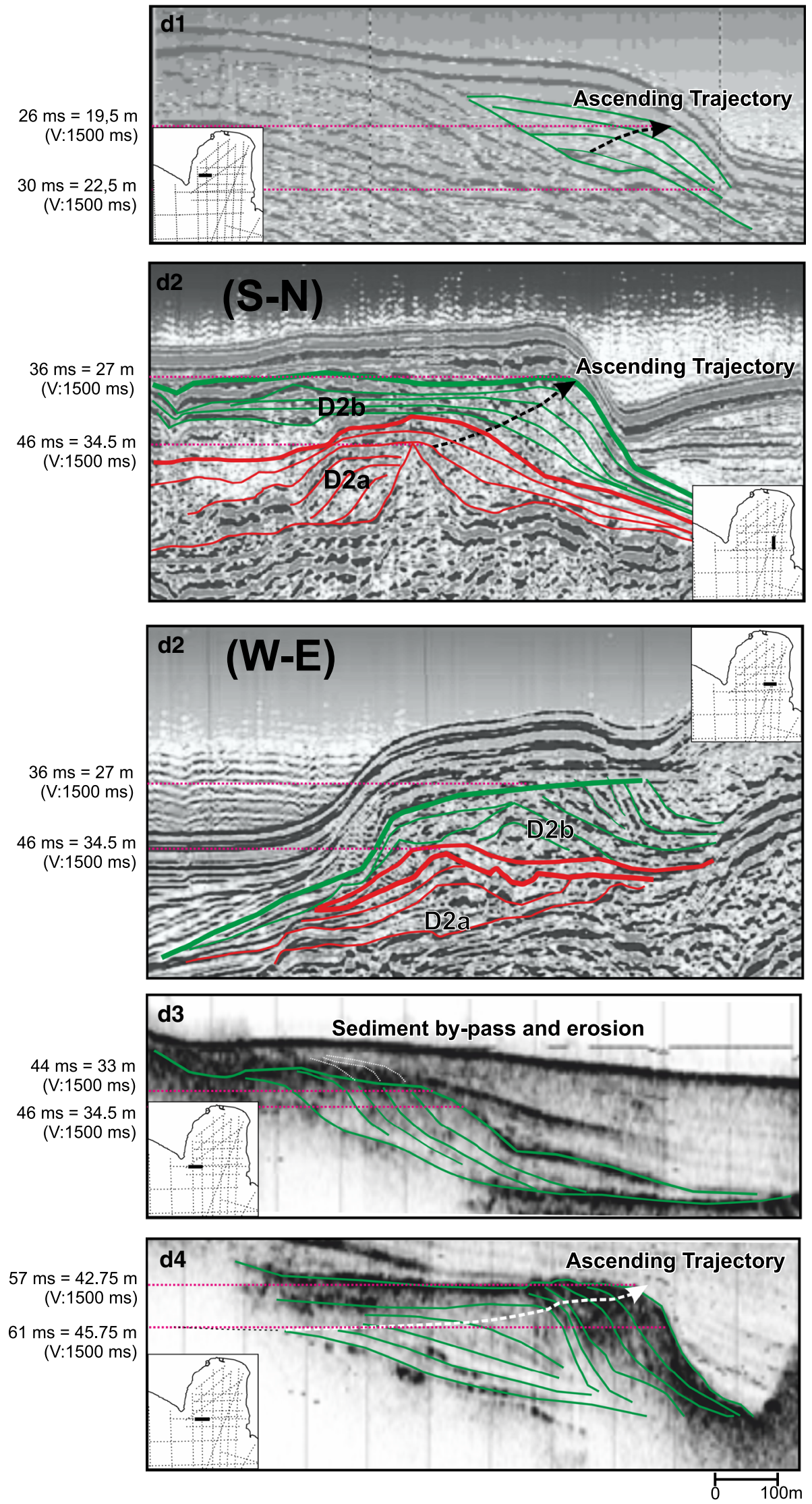

Figure 6. Seismic expression of the shoreline clinoforms that were represented by the Units D1, D2, D3 and D4 in the text. Dashed arrow lines show the trajectories of the topset foreset transitions, which is eroded in D3. 


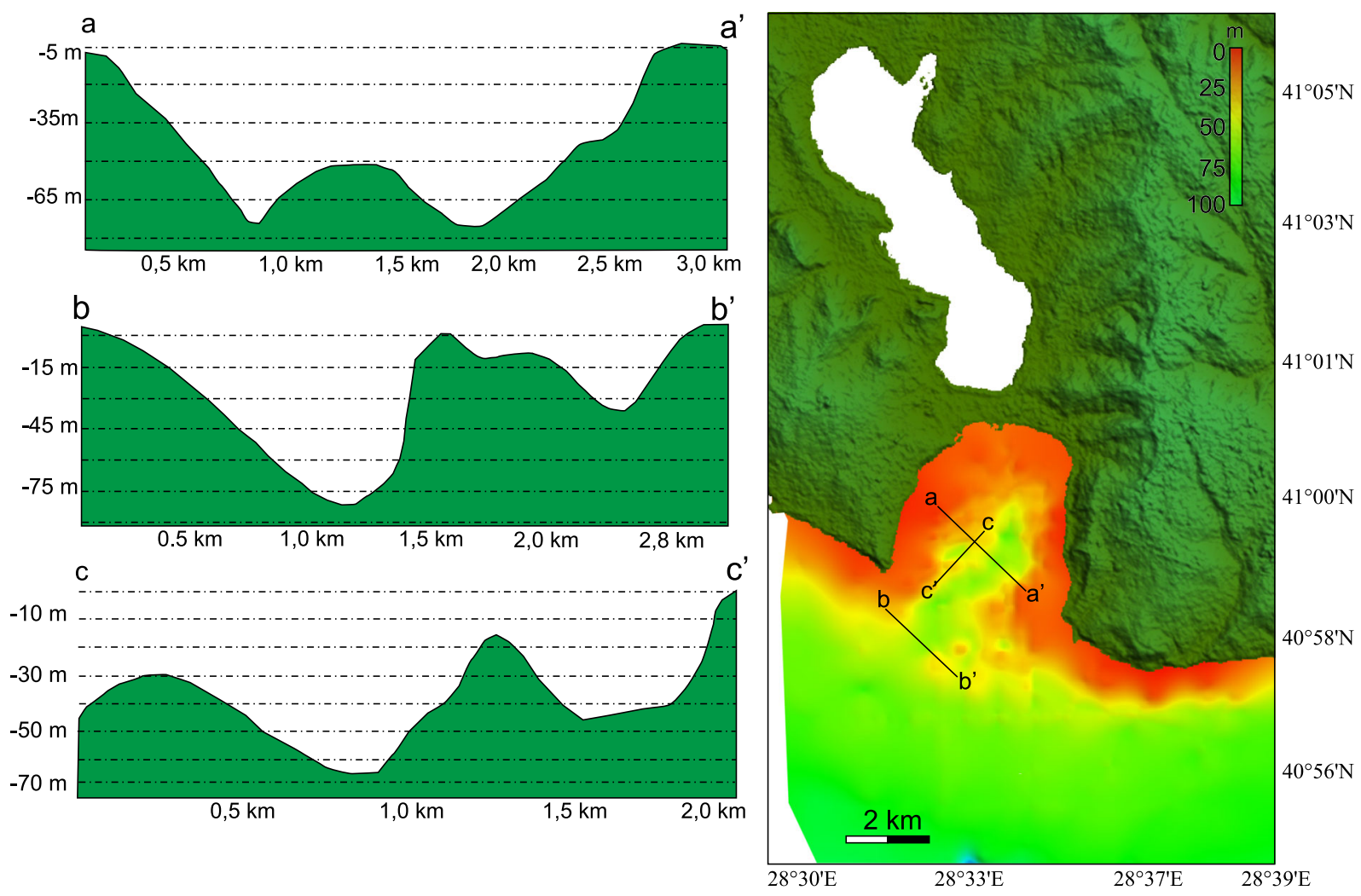

Figure 7. Map and cross sections showing the morphology and present day depth to the erosional truncation surface 3 .

Sea. Gökaşan et al. (2002), for example, outlined only the sedimentary units above the acoustic basement as a single unit. Karakılçık et al. (2014) outlined three distinct Late Quaternary seismic units above the acoustic basement (their SU I) using Uniboom data collected by the Turkish Navy. In the Büyükçekmece Bay, however, they could differentiate only one seismic unit (SU IV), the youngest of their units, directly above the acoustic basement. This most widespread unit with parallel and sub-parallel reflections was interpreted as Holocene deposits. Therefore, the available seismic data obtained from the previous surveys were not sufficient to explain the stratigraphy of the Büyükçekmece Bay in detail, and discuss its depositional history in response to the sea level changes since the LGM.

Considering the overall appearance, reflection characteristic and areal distribution of the seismic units delineated in the present study above the truncation surface $B$, the Büyükçekmece Bay area was a transitional domain between the terrestrial and marine sedimentation during their deposition following the LGM. The total thicknesses of the Units U1a and U1b reach up to $30 \mathrm{~m}$ in the central part of the bay, possibly due to high rates of sediment transportation. The fluvio-marine and marine deposits in the bay are typically represented by several stages in prograding deposits. Slope erosions and basin deepening due to the secondary faults observed along the NE-trending valley control the external shape and reflection configurations of these units.

The prograding shoreline deposits of D1, D2, D3 and D4 represent an important amount of sediment carried by the rivers flowing into the Büyükçekmece lagoon and then to the Marmara Sea through the valleys carved in the erosional surface (figures 7, 8a, b).

The setting of prograding shoreline deposits and their topset-foreset transitions are the final products of five main factors. They are: (a) the initial bathymetry of the Büyükçekmece Bay, (b) the changes in sediment supply, (c) the suspended sediment concentration that is mostly riverine, $(\mathrm{d})$ the eustatic sea-level changes following the Mediterranean invasion through the Dardanelles Strait and finally, and (e) the total subsidence. The types of shoreline trajectories of D1-D4 depend on the sedimentation and progradation rates during their evolution (figure 6).

The prograding shoreline deposits at the western side of the Büyükçekmece Bay contain some incised valley fills. On the other hand, Unit D2 that 


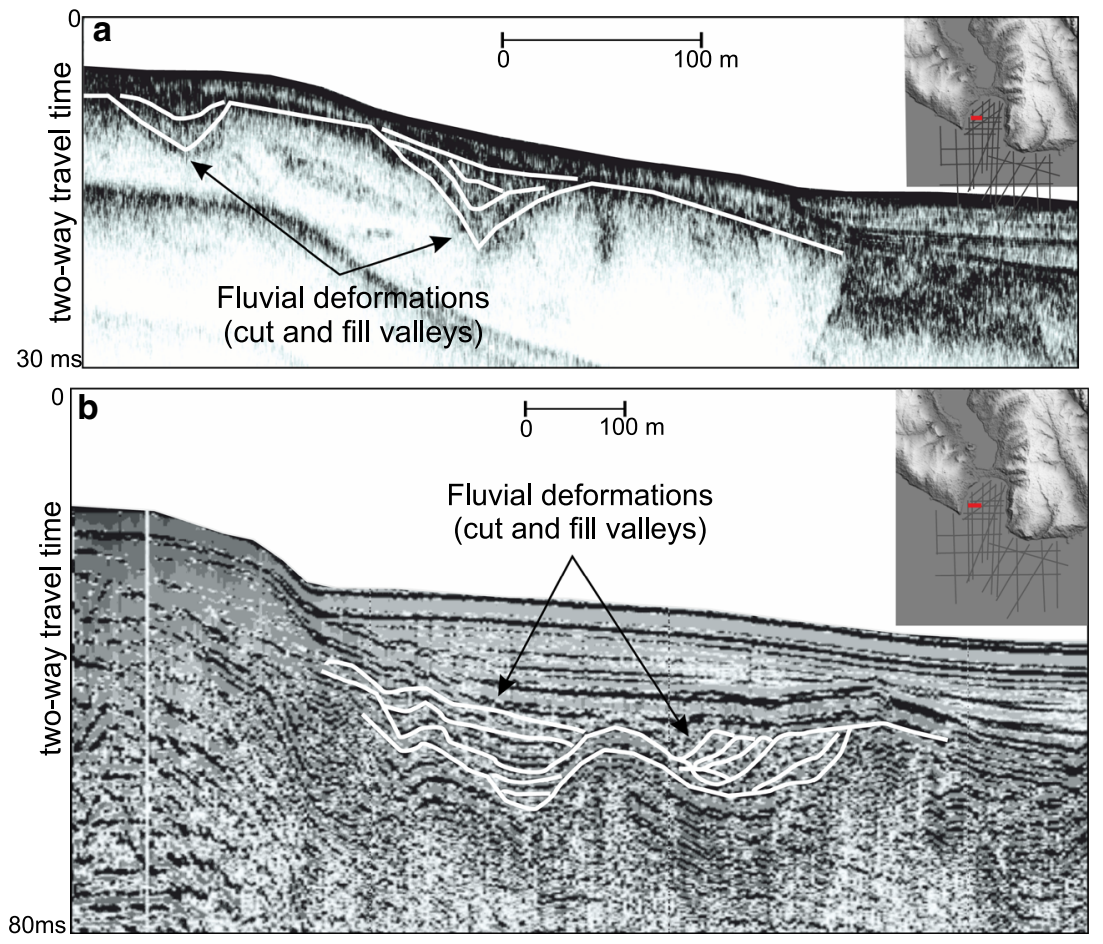

Figure 8. Small-scale cut and fill valleys observed on the (a) CHIRP and (b) Sparker data. Insets show the locations of the sections.

is located at the eastern side is normal distributary channels. The general characteristics of these prograding deposits imply that they were formed by fine-grained sediments transported by riverine discharges. The alluvial material carried by two incised river valleys, observed on the erosional truncation surface $B$ (figures $7 \mathrm{a}, \mathrm{b}, \mathrm{c}, 8 \mathrm{a}, \mathrm{b}$ ), are largely responsible for the formation of prograding clinoforms of the Units D1, D2, D3 and D4 (figure 9).

\subsection{Integration between the Holocene sea level fluctuations with delta deposition}

Considering the sea-level changes during and after the last glaciation (e.g., Lambeck et al. 2007; Aksu et al. 2016) and wave base level in the Marmara Sea, it will be possible to estimate the ages of development of the prograding shorelines. The wave base level in the modern systems of the Marmara Sea is at the water depths from 10 to $15 \mathrm{~m}$ (Aksu et al. 1999; Hiscott et al. 2002). From their seismic expressions, the development of these late glacial-Holocene prograding shoreline units took place between 7300-7800, 8300-9100, 9000-9100, 9650-9900 BP for D1, D2, D3 and D4, respectively (figure 9). The probable coastal shorelines at those times come to the present day depth contours of $9,17,23$ and $33 \mathrm{~m}$ below the modern sea level (figure 9). These depth values show that the prograding shoreline deposits must have completed their development within 500-800 years.

The characteristic seismic features of the sediment deposition, incised valleys and erosional surfaces are similar, but in smaller areal scale, to those observed at the southern canyon of the Bosphorus Strait (figure 10) as given by Köprülü et al. (2016). The fluvial erosion (see figure $3 \mathrm{~d}$ ) caused by strong flows coming from the northern sector separated the Unit D4 into two parts and prevented further sediment accumulation along the underwater valley.

4.2 Similarities in depositional history between the Büyükçekmece Bay and the southern outlet of the Bosphorus Strait

The region at the southern outlet of the Bosphorus Strait, where the most prominent morphological feature is an asymmetric canyon, is the most important depositional and erosional area along the northern shelf (Aksu et al. 1999; Algan et al. 2001; Hiscott et al. 2002; Gökaşan et al. 2005; Eriş et al. 2007; Köprülü et al. 2016). Under the strong two-layer current system, the western slope of this canyon is steeper than the eastern one. The canyon in the Büyükçekmece Bay is similar to the 


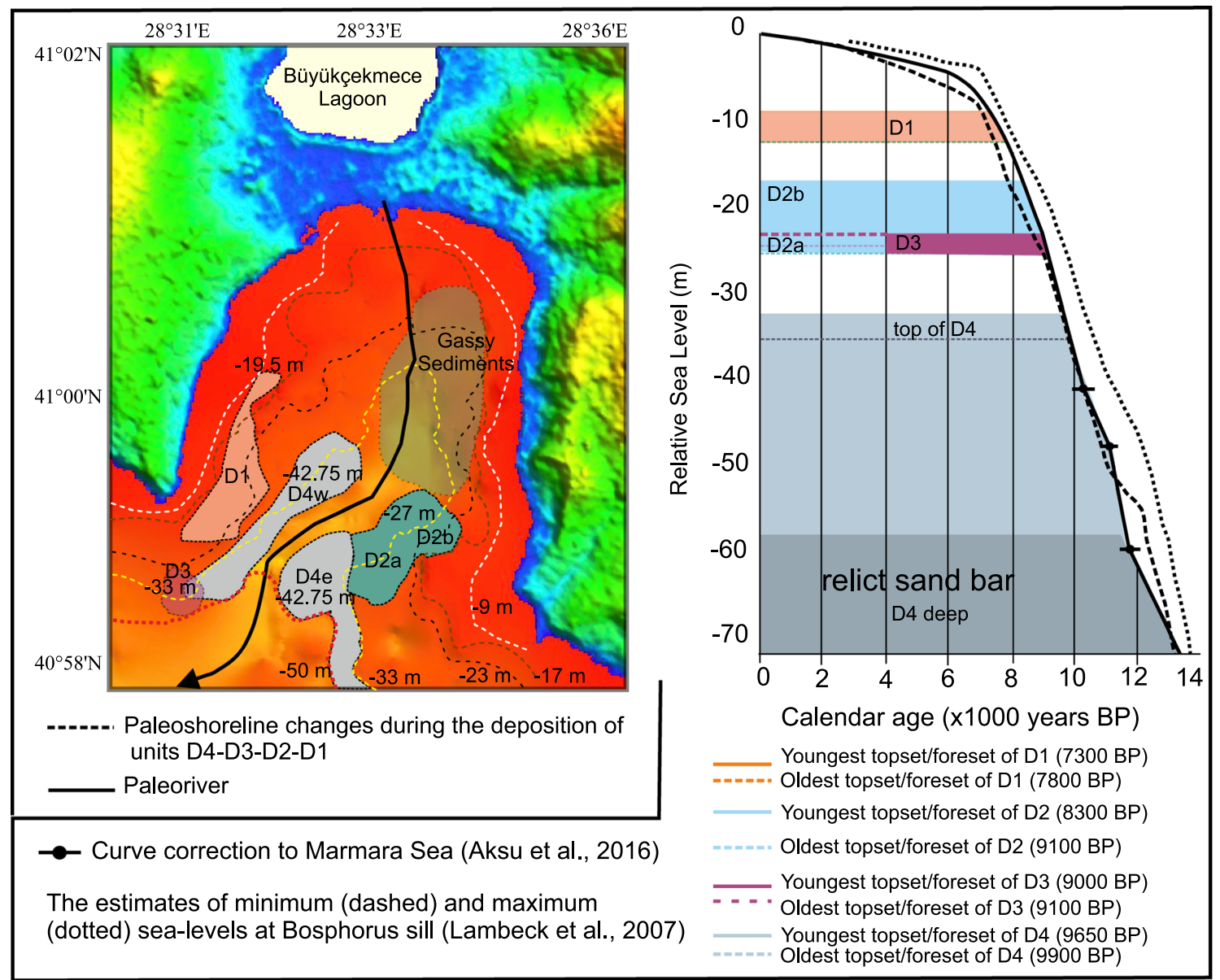

Figure 9. Map shows the paleo-river suggested in this study and relation with the prograding shoreline deposits in the Büyükçekmece Bay. Figures show the depths (in metres below present mean sea level) to the top surface of the prograding shoreline deposits. The development of the Units D1-D4 depends on the sea-level rise in Holocene (MIS-1) proposed by Lambeck et al. (2007) and Aksu et al. (2016).

Bosphorus canyon, but it is smaller. It looks like a mirror image of the Bosphorus canyon drawn along a WE-trending profile, but with a steeper eastern slope (figure 10). Such a morphological feature indicates an outflow to the south, therefore a significant erosion, along the fault-controlled valley in the Büyükçekmece Bay (figure 3a).

The sources and evolution mechanism of the deltaic sequence at the southern outlet of the Bosphorus Strait is still unknown and a subject of debate today (Unit 1b, Köprülü et al. 2016). The topset-foreset transitions of this deltaic accumulation, which is thicker than $30 \mathrm{~ms}$ two-way-travel time below mean sea level, have an ascending character (Hiscott et al. 2002) and its long-distance spatial continuity shows high amount of terrestrial input during the deposition against the sea-level rise (Köprülü et al. 2016). The delta (Unit 1b) is located between 38 and $58 \mathrm{~m}$ below the modern sea level (Köprülü et al. 2016).
The sigmoid Units D3 and D4 observed in the Büyükçekmece valley are similar to the deltaic Unit 1b (sD3 and sD4 in AA' section in figure 10) in terms of depths below sea level and reflection characteristics. The main differences between the units are in their sizes and geometry, which are directly related with the rate of sediment input against the sea-level rise in the Marmara Sea. The topset-foreset transitions of Unit D4 have also an ascending character similar to those in Unit 1b. The top of Unit D4 is about $42.75 \mathrm{~m}$ below the modern sea level and effects of wave erosion can be seen on its frontal lobe (figures 3b, 6). This unit retreated backward rapidly according to the sea level rise and then continued its accumulation under the name of Unit D3 with some downlap terminations on the Unit D4. The topsetforeset transitions of Unit D3 have a descending character, implying sediment by-pass towards the deep basin. The top of Unit D3 is at $33 \mathrm{~m}$ below the 


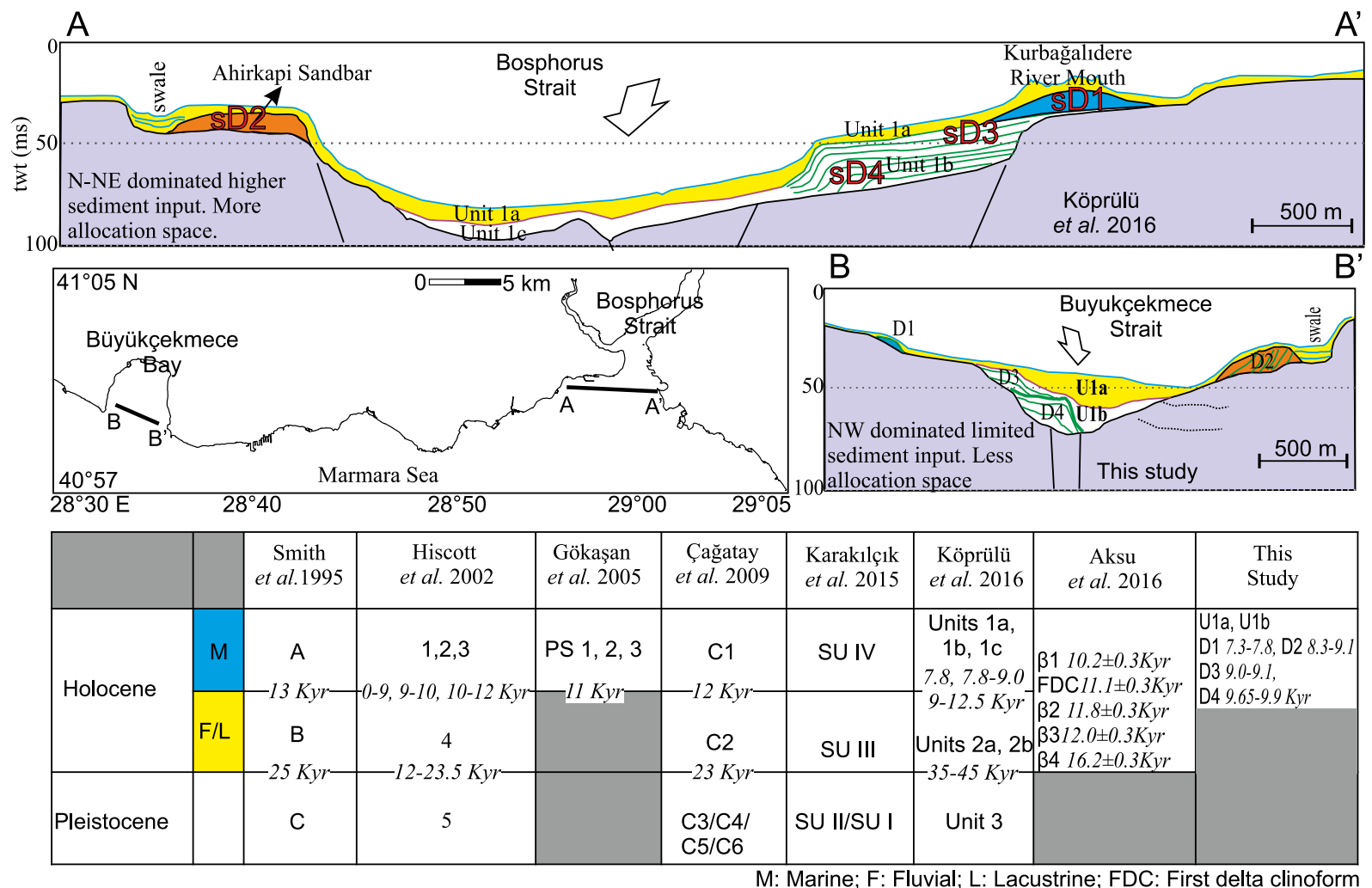

Figure 10. The comparison of the interpreted stratigraphic sketch section we deduced from the Büyükçekmece Bay with that at the southern outlet of the Bosphorus Strait (Köprülü et al. 2016) demonstrate similar morphologic settings and seismic units.

present mean sea level. The subunit D1 is similar to the seismic image of fluvial depositions (Unit 1a of Köprülü et al. 2016 at the mouth of the Kurbağalıdere River; here named sD1 for comparison) observed at the eastern part of the Bosphorus Strait, whereas it is overlain here by marine origin sediments due to lack or low rate of terrestrial sediment input. Finally, Unit D2 in the eastern part of the Büyükçekmece Bay is similar to the sand bars (see sD2 on the cross-section A-A') observed on the western side of the Bosphorus Strait (Alpar et al. 2012) in terms of their depths below the present mean sea level and reflection characteristics. Similar to the swale behind the Ahirkapi sandbar (Köprülü et al. 2016), a fluviatile erosion area is located between the complex Unit D2 and the land (see also figure $3 \mathrm{~b}$ ).

From the point of their morphological characteristics and Late Quaternary depositional properties, the depositional basin in the Büyükçekmece Bay is rather similar to that at the southern outlet of the Bosphorus Strait (figure 10). Their morphological physiography and depositional spaces are like a mirror reflection of the other. In the light of these findings, we propose that the hydrodynamic conditions, erosional and depositional processes in the Büyükçekmece valley during the Late Quaternary were mainly under the control of strong flows coming from the north similar to those along the Bosphorus Strait. The faults at the southern end of Bosphorus, which were developed depending on an anti-clockwise rotation mechanism generated by the dextral shear (Yılmaz 2007), controls the morphotectonic development and present morphology of this outlet area. Therefore, the outflows in both cases, Bosphorus and Büyükçekmece Bay, are along the eroded valleys that are controlled by old faults (figure 10). The differences in the younger units show that the northerly flows in the Büyükçekmece region were less important compared to the Bosphorus flow, but more vulnerable to the sea level rise, possibly due to decreased sediment input.

\section{Acknowledgements}

This work was supported by Scientific Research Projects Coordination Unit of Istanbul University, Project numbers ONAP-41866 and BEK-201623137. 


\section{References}

Aksu A E, Hiscott R N and Yaşar D 1999 Oscillating Quaternary water levels of the Marmara Sea and vigorous outflow into the Aegean Sea from the Marmara Sea-Black Sea drainage corridor; Mar. Geol. 153 275-302.

Aksu A E, Hiscott R N, Mudie P J, Rochon A, Kaminski M A, Abrojano T and Yaşar D 2002a Persistent Holocene outflow from the Black Sea to the Eastern Mediterranean contradicts Noah's flood hypothesis; GSA Today $\mathbf{1 0}$ $3-7$.

Aksu A E, Hiscott R N, Kaminski M A, Mudie P J, Gillespie $\mathrm{H}$, Abrojano T and Yaşar D 2002b Last glacial-Holocene paleoceanography of the Black Sea and Marmara Sea: Stable isotopic, foraminiferal and coccolith evidence; Mar. Geol. 190 119-149.

Aksu A E, Yaltırak C and Hiscott R N 2002c Quaternary paleoclimatic-paleoceanographic and tectonic evolution of the Marmara Sea and environs; Mar. Geol. 190 9-18.

Aksu A E, Hiscott R N and Yaltırak C 2016 Early Holocene age and provenance of a mid-shelf delta lobe south of the Strait of Bosphorus, Turkey, and its link to vigorous Black Sea outflow; Mar. Geol. 380 113-137, https://doi.org/10. 1016/j.margeo.2016.07.003.

Alavi S N, Okyar M and Timur K 1989 Late Quaternary sedimentation in the Strait of Bosphorus: High resolution seismic profiling; Mar. Geol. 89 185-205.

Algan O, Çăgatay N, Chepalyga A, Ongan D, Eastoe C and Gökaşan E 2001 Stratigraphy of the sediment infill in the Bosphorus Strait: Water exchange between the Black and Mediterranean Seas during the Last Glacial-Holocene; Geo-Mar. Lett. 20 209-218.

Alpar B, Ünlü S, Vardar D and Köprülü K 2012 Stratigraphy and dynamics of the Ahırkapı sand bar, Istanbul, Turkey; In: Proceedings of International Conference on LandSea Interactions on the Coastal Zone, Jounieh-Lebanon (eds) Chouikhi A, Khalaf G and Abboud-Abi Saab, 0608 November 2012 pp. 391-398.

Çă̆atay M N, Algan O, Sakınç M, Eastoe C J, Balkıs N, Ongan D and Caner H 1999 A mid-late Holocene sapropelic sediment unit from the southern Marmara Sea shelf and its palaeoceanographic significance; Quat. Sci. Rev. 18 531-540.

Çağatay M N, Görür N, Algan O, Eastoe C J, Tchapalyga A, Ongan D, Kuhn T and Kuşçu I 2000 Late Glacial-Holocene paleoceanography of the Sea of Marmara: Timing of connections with the Mediterranean and the Black Seas; Mar. Geol. 167 191-206.

Çağatay M N, Görür N, Polonia A, Demirbağ E, Sakınç M, Cormier M H, Capotondi L, McHugh C, Emre Ö and Eriş K 2003 Sea-level changes and depositional environments in the Izmit Gulf, eastern Marmara Sea, during the late glacial-Holocene period; Mar. Geol. 202 159-173.

Çăgatay M N, Eriş K, Ryan W B F, Sancar Ü, Polonia A, Akçer S, Biltekin D, Gasperini L, Görür N, Lericolais G and Bard E 2009 Late Pleistocene-Holocene evolution of the northern shelf of the sea of Marmara; Mar. Geol. 265 87-100.

Çăgatay M N, Wulf S, Sancar Ü, Özmaral A, Vidal L, Henry P, Appelt O and Gasperini L 2015 The tephra record from the Sea of Marmara for the last ca. $70 \mathrm{ka}$ and its palaeoceanographic implications; Mar. Geol. 361 96-110.
Eriş K K, Ryan W B F, Çă̆atay M N, Sancar U, Lericolais G, Menot G and Bard E 2007 The timing and evolution of the post-glacial transgression across the Sea of Marmara shelf south of İstanbul; Mar. Geol. 243 57-76.

Eriş K K, Ryan W B F, Çă̆atay M N, Lericolais G, Sancar U, Menot G and Bard E 2008 Reply to Comment on "the timing and evolution of the post-glacial transgression across the Sea of Marmara shelf south of Istanbul" by Hiscott et al.; Mar. Geol. 254 230-236.

Gökaşan E, Gazioğlu C, Alpar B, Yücel Z Y, Ersoy Ş, Gündoğdu, O, Yaltırak C and Tok B 2002 Evidence of NW extension of the North Anatolian Fault Zone in the Marmara Sea: A new interpretation of the Marmara Sea (İzmit) earthquake on 17 August 1999; Geo-Mar. Lett. 21 183-199.

Gökaşan E, Algan O, Tur H, Meriç E, Türker A and Şimşek M 2005 Delta formation at the southern entrance of Istanbul Strait (Marmara Sea, Turkey): A new interpretation based on high-resolution seismic stratigraphy; Geo-Mar. Lett. 25 370-377.

Hiscott R N, Aksu A E, Yaşar D, Kaminski M A, Mudie P J, Kostylev V E, MacDonald J C, İşler F I and Lord A R 2002 Deltas south of the Bosphorus Strait record persistent Black Sea outflow to the Marmara Sea since $\sim 10 \mathrm{ka}$; Mar. Geol. 190 95-118.

Hiscott R N, Aksu A E and Mudie P J 2008 Comment on the timing and evolution of the post-glacial transgression across the Sea of Marmara shelf south of Istanbul by Eris et al.; Mar. Geol. 243 57-76.

Karakılçık H, Unlugenç U C and Okyar M 2014 Late glacialHolocene shelf evolution of the Sea of Marmara west of Istanbul; J. African Earth. Sci. 100 365-378.

Köprülü K, Alpar B and Vardar D 2016 Last GlacialHolocene stratigraphic development at the Marmara Sea exit of the Bosphorus Strait, Turkey; Mar. Geophys. Res. 37 21-35.

Lambeck K, Sivan D and Purcell A 2007 Timing of the last Mediterranean Sea-Black Sea connection from isostatic models and regional sea-level data; In: The Black Sea Flood Question: Changes in Coastline, Climate and Human Settlement (eds) Yanko-Hombach V, Gilbert A S, Panin N and Dolukhanov P M, Springer, The Netherlands, pp. 797-808.

Olgun N Y 2001 Assessing the southern shelf of İstanbul (Ahırkapı-Büyükçekmece) by shallow seismic data; Institute of Marine Sciences and Management, İstanbul University, MSc Thesis (in Turkish), 41p.

McHugh C M G, Gurunga D, Giosanc L, Ryan W B F, Mart Y, Sancar U, Burckle L and Çağatay M N 2008 The last reconnection of the Marmara Sea (Turkey) to the World Ocean: A paleoceanographic and paleoclimatic perspective; Mar. Geol. 255 64-82.

Nasif A 2016 Investigation of northern shelf of the Marmara Sea using seismic and acoustic data sets, The Graduate School of Natural and Applied Sciences, Dokuz Eylül University, MSc Thesis, 96p.

Posamentier H W and Vail P R 1988 Eustatic controls on clastic deposition II - Sequence and systems tract models; In: Sea-level Changes: An Integrated Approach, Posamentier H W, Ross C A and Van Wagoner J C (eds), Soc. Econ. Paleontol. Mineral. Spec. Publ. 42 125-154. 
Posamentier H W, Allen G P, James D P and Tesson M 1992 Forced regressions in a sequence stratigraphic framework: Concepts, examples, and exploration significance; Am. Assoc. Petrol. Geol. Bull. 76 1687-1709.

Smith A D, Taymaz T, Oktay F, Yüce H, Alpar B, Başaran H, Jackson J A, Kara S and Şimşek M 1995 High resolution seismic profiling in the Sea of Marmara (northwest Turkey): Late quaternary sedimentation and sea-level changes; GSA Bull. 107 923-936.

Tur H, Hoşkan N and Aktaş G 2014 Tectonic evolution of the northern shelf of the Marmara Sea (Turkey): Interpretation of seismic and bathymetric data; Mar. Geophys. Res. 36 1-34.

Vail P R 1987 Seismic stratigraphy interpretation using sequence stratigraphy. Part 1: Seismic stratigraphy interpretation procedure; AAPG Studies in Geology $\mathbf{2 7}$ $1-10$.

Van Wagoner J C, Posamentier H W, Mitchum R M, Vail P R, Sarg J F, Louit T S and Hardenbol J 1988 An overview of the fundamentals of sequence stratigraphy and key definitions; In: Sea-Level Changes: An Integrated Approach (eds) Wilgus C K, Hastings B S, Kendall C G St C, Posamentier H W, Ross C A and Van Wagoner J C, SEPM Spec. Publ. 42 39-45.

Vidal L, Menot G, Joly C, Bruneton H, Rostek F, Çağatay M N, Major C and Bard E 2010 Hydrology in the Sea of Marmara during the last 23 ka: Implications for timing of Black Sea connections and sapropel deposition; Paleoceanography 25 PA1205, https://doi.org/10.1029/ 2009PA001735.

Yıldırım M, Tonaroğlu M, Selçuk M E and Akgüner C 2013 Revised stratigraphy of the tertiary deposits of Istanbul and their engineering properties; Bull. Eng. Geol. Environ. $72413-420$.

Yilmaz Y 2007 Morphotectonic evolution of the southern Black Sea region and the Bosphorus Channel; In: The Black Sea Flood Question: Changes in the coastline, climate and human settlement (eds) Yanko-Hombach V, Gilbert A, Panin N and Dolukhanov P, Springer, Dordrecht, pp. 537-569.

Corresponding editor: D SHANKAR 